\title{
The Impact of Learning Culture of High Schools on Learner Autonomy in Private University Preparatory Schools (A Case of Erbil)
}

\author{
Emine Bala*, Ali Bala \\ Department of English Language Teaching, Education Faculty, Tishk International University (Previously Ishik University), Iraq
}

Received August 13, 2020; Revised September 25, 2020; Accepted October 19, 2020

\section{Cite This Paper in the following Citation Styles}

(a): [1] Emine Bala, Ali Bala, "The Impact of Learning Culture of High Schools on Learner Autonomy in Private University Preparatory Schools (A Case of Erbil)," Universal Journal of Educational Research, Vol. 8, No.11B, pp. 6200 - 6207, 2020. DOI: 10.13189/ujer.2020.082258.

(b): Emine Bala, Ali Bala (2020). The Impact of Learning Culture of High Schools on Learner Autonomy in Private University Preparatory Schools (A Case of Erbil). Universal Journal of Educational Research, 8(11B), 6200 - 6207. DOI: 10.13189/ujer.2020.082258.

Copyright $(2020$ by authors, all rights reserved. Authors agree that this article remains permanently open access under the terms of the Creative Commons Attribution License 4.0 International License

\begin{abstract}
This study commenced upon the university preparatory English teacher's perceptions about the lack of their student's readiness for learner autonomy. The impact of students' educational background and learning culture in high schools on learner autonomy in university preparatory classes were examined accordingly. Both quantitative and qualitative methods were applied to obtain the data in depth for this study. Within this context, the researchers designed and distributed a questionnaire to preparatory students in a private university in Erbil, and 70 students participated in this stage. The obtained data were analyzed through SPSS 25 software program. Also, the researchers interviewed with preparatory school instructors to have their perceptions about students' present autonomy level. Initially, the students' perceptions of former learning culture were examined according to their educational background information, and then the level of present readiness for autonomy was analyzed. According to the results, the students believe their teachers in high schools were authoritarian, so they were not given opportunities to enhance their skills to be autonomous learners. Their present teacher-dependent attitudes which came from high school still prevent them from being autonomous learners. However, the encouragement of the preparatory school's instructors helps the students boost motivation to be self-directed learners. This study will shed light on the problems such as teacher-dependent students of the education systems based on rote-learning and guide the
\end{abstract}

curriculum designers and school teachers to take the urgency of learner autonomy into consideration in language teaching.

Keywords Educational Background, High School, Learner Autonomy, Learning Culture, Rote Learning, Self-directed Learners, Teacher-dependent Students, University Preparatory School

\section{Introduction}

Some of the popular topics in language teaching are to explore how to teach a foreign language more effectively and efficiently, how to activate the learners inside and outside the classroom, and how to make the language learners as lifelong learners. Being able to achieve all these things is quite hard for either teachers or learners. Authoritative teachers, rote-learning based education system, improper methods or techniques unenthusiastic or inattentive students are some of the challenges which make language classes ineffective. To eliminate these barriers, the scholars have contemplated to find out new approaches, methods and techniques to clear up this way for several decades.

In recent years, most of the researches have emphasized that learner autonomy is one of the key factors in language 
learning beside all the studies in that discipline. Most of the teachers state that if the learners cannot gain autonomy, teaching and learning process cannot work properly. Consequently, the studies about learner autonomy and the related ones such as learning culture, learning types or language learning strategies have gained popularity. If the learner does not take responsibility for his/her own learning, he/she becomes a teacher- dependent, diffident, inattentive, or unmotivated learner which inhibits the language acquisition. Hence, he/she should use or enhance his/her abilities, actively participate inside or outside the classroom activities, and have motivation to continue his/her learning process. Furthermore, the students should be supported by the teachers, school administration and the parents to strengthen their skills to be autonomous learners.

The learning culture of schools may directly affect the students' autonomy level. "The term culture of teaching and learning refers to the attitude of educators and learners towards teaching and learning, and the spirit of dedication and commitment in a school which arises through the joint effort of school management, the input of educators, the personal characteristics of learners, factors in the family life of learners, school-related factors as well as societal factors" [17]. If a school's education system is based on rote-learning, students cannot find the opportunities to take responsibility for their own learning. Furthermore, if the teachers do not give the students enough freedom that helps them improve autonomy skills, the learners cannot take responsibility for their own learning.

Research Problem, Objectives and Questions:

In this study, the impact of former language learning culture of preparatory students on their present learning autonomy level was analyzed. Most of the students are the graduates of the governmental schools at this university. In Iraq (Kurdistan Region), high school students prepare for university admission examination mostly relying on memorization method in English language part. Also, according to Khamees [6], the foreign language teaching comprises of the translation or copy of the language items without learning them in meaningful contexts. They must achieve in all subjects to gain a remarkable mark to be accepted as a university student. At the end, not all of the students have the chance to study the majors which they desire. According to their points, they apply to any departments which their points match.

One of the prominent publishing house's book series which have been adapted to Kurdish culture for English course from the first-grade primary to the twelfth-grade high school are employed in public schools. They created a webpage of the book in which all materials are supplied both for the teachers and the learners including supplementary class resources such as the recommended exams, grammar reference materials, word lists, teacher training manual, student's and activity books or CDs through the webpage. Most of the grade-twelve-students tend to memorize the structures and the stories for the university admission examination rather than acquiring the target language because the questions in the language part are formed according to those structures and the same stories. Thus, the system forces the schools, teachers and the students to create a language culture which is mostly dominated by rote-learning and to make the students more dependent.

However, the private university where this study has been conducted aims to cultivate the students regarding their natural talents, skills and desires, so most of the preparatory students have difficulty in adapting to new system. The language teachers indicate that the majority of the students continue their former learning culture by memorization the structure for the exam rather than focusing on the application and practicing the language inside/outside the classroom, or they avoid to take responsibility for their own learning or endeavoring to foster their ability to be autonomous learners. In this sense, the following questions are sought to find out in this study:

- What are the students' perceptions for their autonomy level at their high schools?

- What are the students' perceptions for their current readiness for autonomy at preparatory school?

- How do the students define their motivational level?

- Is the students' autonomy level affected by the high school learning culture?

\section{Literature Review}

Council of Europe Modern Language Project revealed the idea of learner autonomy in 1971. In the following year, the project started to be carried out by Henri Holec who was the pioneer of the learner autonomy [6]. The idea of learner autonomy has been essential for the reformist educational principles; however, it has become focal point in foreign language teaching since 1979 after the publication of Henri Holec's book, Autonomy and Foreign Language Learning, by Council of Europe Modern Language Project in which the autonomy emphasizes as 'the ability to take charge of one's own learning' [4]. Primarily, that concept drew little attention either theoretically or classroom activity guiding fundamental, but later especially at the end of 1990 s, it has been the popular phenomena of foreign language teaching. That is to say that, the studies about the significance of curricular reforms in European countries that emphasized the learner's capacity enhancement for liberated ideas and critical thinking and assisting them to learn how to learn [9].

Autonomy derived from the Greek word autónomos, which means living under one's own rules, independency. Autonomy and self-control state the same situation which is the ability of controlling somebody's own opinions, learning and activities [12]. Learner autonomy is to take responsibility for one's own learning that indicates the 
students learn on their own more adequately. Additionally, they may have more efficient learning process since they manage it on their own in terms of deciding the readiness for learning [7].

Little [8] describes autonomy as an ability to fulfill self-reliant activities, controlling the process or analytical thinking. The students will create a specific psychological connection to the process and essence of his learning. Teachers are literally responsible for learning according to the traditional way on behalf of some higher agency such as school or educational authorizations. In this system, the students' concerns, requirements or ambitions are disregarded. The alteration of learning responsibility from teacher to the student has remarkable results in terms of the changing system of educational organizations and the interactions of students-teachers. Presently, the students create their own learning intentions including the content and methods, and decisions on the success of the learning process and target achievements. Furthermore, the researchers primarily focused on the propensities for prospering learners to learn foreign language. The previous researchers highlighted the description and classification of learning patterns of the students. It has been recognized that competent language learners are more capable of enhancing their learning ability [1]. Learner autonomy is prerequisite for foreign language learning considering that it is an everlasting process, not just inside the walls.

Little [8] claims that the basis of learner autonomy is willful, active and thoughtful contribution on somebody's own learning. Learner autonomy is not fundamental intention however it is the way which the teachers operate students' agency or capacity to act. The learning process relies upon the actions and ambition of the students much more rather than any inputs transferred from teachers or textbooks to the students. Therefore, learner autonomy involves the students' identity perception, knowledge and experience that students acquire outside the classroom.

Palfreyman and Smith [12] highlight the situational circumstances under which learner autonomy could improve. Within this scope, the process of learning alone and making one's own instructional decisions without help of the teacher, school or tutors may be either encouraging or discouraging based on the students' aims and learning styles. That is, if the students are introvert who generally prefer studying or learning alone could be satisfactorily inspiring; yet it is not appropriate and could be demotivating for the extraverts who need to interact with the people and develop communication skill or concrete sequential learners who need assistance from their teachers or counsellors.

Gholami [3] advocates that western educational systems' adaptation to autonomy practice and self-access seems more successful comparing to non-western educational systems. There is a general understanding today about non-western students are believed to be unfamiliar with learner autonomy. However, the teachers should provide consultation for the strategies of autonomy. In furtherance of the students' consolidation in autonomy and self-access, there are several methods like strategy training, self-assessment, journals, distance learning and learning diaries. Additionally, supporting of the students' present autonomy by the teachers can be accepted as an essential foundation for their advanced development; in fact, several advocates claim the idea of the students have authority and right for learning on their own as a major principle. On the contrary, other methods and student training programs which are applied on the students to make them 'the ideal autonomous learners could support the criticism of the nonwestern students' inappropriateness for autonomy because it is a western conception [13].

According to Palfreymen [11], "A common way of interpreting culture is to refer to national/ethnic cultures such as Chinese culture or Western culture e. Western educators mostly boost the concept of learner autonomy however some problems have occurred while applying it in other communities that's why the cultural dissimilarities between West and other societies. So, one significant question has emerged if the concept of learner autonomy is monocultural.

Traditional methods and beliefs of various types of societies are defined as another perception of culture such as school or classroom culture. Learner autonomy has occasionally been associated with specific types of place, particularly self-access centers. The last application of the idea of culture links with the students in sociocultural circumstances are opposite to the students in aloneness. Autonomy is constantly associated with a target on the individual learner, yet with cultural context considered as either it confines the learner freedom or as unrelated to it.

Nonetheless, sociocultural conditions and collaboration with others are significant characteristics of education and our lives.

The features of autonomous learners are specified in the psychological research as high motivation; self-sufficiency, affirmative approaches, need for accomplishment and both the extrinsic and intrinsic motivation. Learners are motivated extrinsically when they learn by reason of rewards like marks or praise which are not related to the learning itself directly. On the other hand, learners are motivated intrinsically if they learn for the sake of learning itself, or the feeling of accomplishing the tasks. Learning approaches, some particular stages or plans which are utilized by most of the learners to augment their learning are mostly considered as a psychological gateway to L2 learner autonomy [12].

School managers may stimulate students' success by caring the learning culture at school. The schools which aim 'goal focus, communication, optimal power equalization, resource utilization, cohesiveness, morale, innovativeness, autonomy, adaptation and problem solving adequacy' are defined as healthy schools. In order to change and develop the results of schooling for either 
teachers or learners, the characteristics of the school culture should be modified. Supportive and competent school cultures that reveal the positive school climate will give support to enhance the students' achievement [10]. Teaching and learning (academic climate) are accepted among four main dimensions of a positive school climate. If teaching and learning structures are not established as they should be, then the school climate may be affected negatively. Accordingly, the components of teaching and learning such as outcomes, objectives, curriculum, course designs, strategies, plans, etc. have key factors on students' achievement. If one of the significant aims of the education is to raise lifelong learners, the school administration and teachers should encourage the students to develop selfgovernance and self-efficacy to have autonomous learners. The more they take their own learning responsibility, the more they can perpetuate learning in their future life. Otherwise, they remain as dependent individuals who solely memorize the information, use it for short-term goals like examinations and forget it in a short time.

Tran and Duong [15] advocate that the teachers are the managers of the resources of the life-long learning because of their roles to increase learner autonomy. Moreover, teachers are accepted as facilitators and counselors to stimulate students' autonomy. Teachers may assist the students to prepare their own plans, set up learning objectives, decide material selection or assess their learning improvement as facilitators in addition to help them obtain the skills and information to achieve the items above. Besides, teachers counsel the students to raise the awareness of self-efficacy, self-governing, the conscious of taking own learning responsibility and help them to manage their problems in that way. Through this frame, the teacher can inquire her/ his own classroom practice in ELT reflecting on the puzzle observed and intending to improve it to significantly make more effective decisions about teaching.

\section{Methodology}

\subsection{Participants}

The sample of this research comprises of 70 preparatory students and 4 preparatory school teachers of a private university in Erbil. The researchers used personal contacts to reach the study sample, so they employed convenience sampling method for the selection. In this university, the enrolled students for the first year should take an English proficiency exam before the lessons start and accomplish the point that is required to be exempt from preparatory school. The ones who fail in this exam should study one year in preparatory school to improve their English proficiency level. The students take intensive English courses in one year.

\subsection{Instrumentations}

The researchers aim to evaluate the effects of preparatory students' former learning habits on their present autonomy level. In this sense, the mixed method was employed to obtain the data in-depth. According to Cohen, Manion and Morrison [2], mixed method research provides 'more comprehensive and complete understanding of phenomena to be obtained than single methods approaches and answers complex research questions more meaningfully'.

In this study, the researcher adapted a questionnaire from Ustunoglu [17] and Karabiyik [5], and the students' questionnaire items were translated into Kurdish by a Kurdish native English language instructor which was the participants' native language to make the statements clarify regarding the students' low English proficiency level. Then, the Kurdish translation was verified by three Kurdish native English instructors for the reliability of the items. Also, the researchers created the interview questions revealing the teachers' perceptions about the impact of former learning culture on students' present autonomy level based on their observations.

\subsection{Data Collection and Analysis Process}

The researchers asked permission from preparatory school's director to conduct the questionnaire to the students. It was distributed to the students by their teachers during their course time to be able to assist them when they needed. The obtained data were analyzed in SPSS 25 software program. Additionally, four volunteer preparatory school instructors were interviewed in their offices to reveal their perceptions about current students' autonomy level. The items of the interviews were formulated and interpreted consequently according to the inductive approach which promotes an interpretation of meaning in complex data by the creation from the raw data of overview themes or groups [14].

\subsection{Ethics}

The students and the instructors participated in the research were provided confidentiality by giving them code as S1, S2, S3, ... T1, T2, T3, etc. The researchers guaranteed the data would be used just for the research purpose, and the participants' identity would remain anonymous. Also, they ensured the respondents could withdraw their participation at any time without any consequences. 


\section{Findings and Discussion}

\subsection{Students Questionnaire Results}

Table 1. Items reliability

\begin{tabular}{|c|c|c|}
\hline \multicolumn{3}{|c|}{ Reliability Statistics } \\
\hline Cronbach's Alpha & $\begin{array}{c}\text { Cronbach's Alpha Based on } \\
\text { Standardized Items }\end{array}$ & N of Items \\
\hline 0.776 & 0.777 & 62 \\
\hline
\end{tabular}

Data of the student participants $(\mathrm{N}=70)$ was analyzed through the SPSS 25 statistics data editor. The reliability value of the questionnaire is .776, which means the items of the questionnaire have consistency regarding the threshold for Cronbach's alpha should be higher than .700.

Table 2. Statistics of gender, age, English level, former English study year and university admission exam marks

\begin{tabular}{|c|c|c|c|c|c|}
\hline Items & & Frequency & Percent & $\begin{array}{c}\text { Valid } \\
\text { Perce } \\
\text { nt } \\
\end{array}$ & $\begin{array}{c}\text { Cumulative } \\
\text { Percent }\end{array}$ \\
\hline \multirow{3}{*}{ Gender } & Female & 40 & 57.1 & 57.1 & 57.1 \\
\hline & Male & 30 & 42.9 & 42.9 & 100 \\
\hline & Total & 70 & 100 & 100 & \\
\hline \multirow{4}{*}{ Age } & $18-19$ & 49 & 70 & 70 & 70 \\
\hline & $20-21$ & 15 & 21.4 & 21.4 & 91.4 \\
\hline & $>=22$ & 6 & 8.6 & 8.6 & 100 \\
\hline & Total & 70 & 100 & 100 & \\
\hline \multirow[t]{5}{*}{ English Level } & A1 & 13 & 18.6 & 18.6 & 18.6 \\
\hline & A2 & 50 & 71.4 & 71.4 & 90 \\
\hline & B1 & 3 & 4.3 & 4.3 & 94.3 \\
\hline & B2 & 4 & 5.7 & 5.7 & 100 \\
\hline & Total & 70 & 100 & 100 & \\
\hline \multirow{6}{*}{$\begin{array}{l}\text { Former English } \\
\text { study year }\end{array}$} & $<1$ & 20 & 28.6 & 28.6 & 28.6 \\
\hline & $\begin{array}{c}1-3 \\
\text { years }\end{array}$ & 30 & 42.9 & 42.9 & 71.4 \\
\hline & $4-6$ & & & & \\
\hline & years & 13 & 18.6 & 18.6 & 90 \\
\hline & $>=7$ & 7 & 10 & 10 & 100 \\
\hline & Total & 70 & 100 & 100 & \\
\hline \multirow{6}{*}{$\begin{array}{l}\text { University } \\
\text { admission } \\
\text { exam marks }\end{array}$} & $45-55$ & 3 & 4.3 & 4.3 & 4.3 \\
\hline & $56-65$ & 24 & 34.3 & 34.3 & 38.6 \\
\hline & $66-75$ & 19 & 27.1 & 27.1 & 65.7 \\
\hline & $76-85$ & 21 & 30 & 30 & 95.7 \\
\hline & $>=86$ & 3 & 4.3 & 4.3 & 100 \\
\hline & Total & 70 & 100 & 100 & \\
\hline
\end{tabular}

As shown in table 2, the characteristics of the participants are displayed such as statistics of gender, age, English level, former English study year and university admission exam marks.

According to the results, the majority of the participants are female and between 18-19 years old. $90 \%$ of the students' English level is A1 and A2 whereas 10\% of them have level $\mathrm{B} 1$ and $\mathrm{B} 2$ respectively. $71 \%$ of the students studied English three years and below before university preparatory school. The range of the students' university admission marks is equally distributed from 56 to 85 out of 100 .

Table 3. Descriptive statistics of the students' and teachers' roles at high school

\begin{tabular}{|c|c|c|c|}
\hline \multicolumn{4}{|c|}{ Descriptive Statistics } \\
\hline & $\underline{\text { Mean }}$ & $\underline{\text { Std. Deviation }}$ & $\underline{\mathrm{N}}$ \\
\hline Teachers' role & 2.26 & 0.863 & 70 \\
\hline Students' role & $\underline{2.30}$ & $\underline{0.749}$ & $\underline{70}$ \\
\hline
\end{tabular}

The results show that the students' perception about their high school teachers' general profile is that their teachers were mostly authoritarian ( $M=2.26$-from sole authority (1) to facilitator (5)) in learning process which probably prevented the students from being autonomous learners. Furthermore, they identified themselves generally teacher-dependent ( $M=2.30$-from teacher dependent (1) to autonomous (5)) who could not have taken their own learning responsibilities by actively participating in learning process.

Table 4. The correlation of role of the teachers and role of the students at high school

\begin{tabular}{|c|c|c|c|}
\hline & & $\begin{array}{c}\text { the role of your } \\
\text { teachers in } \\
\text { class } \\
\end{array}$ & $\begin{array}{c}\text { your role as a learner } \\
\text { when you were in the } \\
\text { high school }\end{array}$ \\
\hline \multirow[t]{3}{*}{ Teachers' role } & $\begin{array}{c}\text { Pearson } \\
\text { Correlation }\end{array}$ & 1 & $.552 * *$ \\
\hline & $\begin{array}{c}\text { Sig. } \\
\text { (2-tailed) }\end{array}$ & & 0.000 \\
\hline & $\mathrm{N}$ & 70 & 70 \\
\hline \multirow[t]{4}{*}{ Students' role } & $\begin{array}{c}\text { Pearson } \\
\text { Correlation }\end{array}$ & & \\
\hline & & $.552 * *$ & 1 \\
\hline & $\begin{array}{c}\text { Sig. } \\
\text { (2-tailed) }\end{array}$ & 0 & \\
\hline & $\mathrm{N}$ & 70 & 70 \\
\hline
\end{tabular}

Table 3 illustrates the correlation of role of the teachers and role of the students at high school from the students' perspectives. The results show that there is a significant correlation between these two items with 0.000 significance point. Namely, the preparatory school students believe their high school teachers used to be more authoritarian, so the students used to be more teacher-dependent rather than autonomous. 
Table 5. Students' evaluation of their learning engagement at high school

\begin{tabular}{ccccc}
\hline & N Valid & Mean & Minimum & Maximum \\
\hline $\begin{array}{c}\text { participation in group/pair } \\
\text { work activities }\end{array}$ & 70 & 2.04 & 1 & 4 \\
$\begin{array}{c}\text { assessing your own work } \\
\text { assessing your friends' }\end{array}$ & 70 & 2.23 & 1 & 4 \\
$\begin{array}{c}\text { work } \\
\text { choosing your study group }\end{array}$ & 70 & 2.21 & 1 & 4 \\
participation in a project & 70 & 2.00 & 1 & 4 \\
$\begin{array}{c}\text { work } \\
\text { selecting the activity types }\end{array}$ & 70 & 2.06 & 1 & 4 \\
$\begin{array}{c}\text { for the lessons } \\
\text { selecting the classroom } \\
\text { materials }\end{array}$ & 70 & 1.89 & 1 & 4 \\
$\begin{array}{c}\text { setting learning objectives } \\
\text { assessing your courses }\end{array}$ & 70 & 2.01 & 1 & 3 \\
deciding on what to learn & 70 & 1.91 & 1 & 4 \\
next & 70 & 2.30 & 1 & 4 \\
portfolio preparation & 70 & 1.43 & 1 & 3 \\
\hline
\end{tabular}

The table above illustrates the students' evaluation about to what extent the students were involved in learning process by their teachers at high school. The average mean $(M=2.04)$ is in 'rarely' part which proves the students were not given enough chance to be autonomous learners. The maximum mean is 2.30 which represents the item of asking the students to decide what to learn next whereas the minimum mean $(M=1.43)$ is on asking students to prepare portfolios which has a great impact on being an autonomous learner and students' self-improvement.

Table 6. Students' responsibility perception

\begin{tabular}{|c|c|c|c|c|}
\hline & $\begin{array}{c}\mathrm{N} \\
\text { Valid }\end{array}$ & Mean & Minimum & Maximum \\
\hline $\begin{array}{c}\text { making advancement during } \\
\text { lessons }\end{array}$ & 70 & 2.70 & 1 & 4 \\
\hline $\begin{array}{c}\text { making advancement outside } \\
\text { class }\end{array}$ & 70 & 3.33 & 1 & 5 \\
\hline $\begin{array}{l}\text { increasing your curiosity in } \\
\text { language learning }\end{array}$ & 70 & 2.57 & 1 & 5 \\
\hline diagnosing your weaknesses & 70 & 2.33 & 1 & 5 \\
\hline studying harder & 70 & 2.36 & 1 & 5 \\
\hline $\begin{array}{l}\text { decide the objectives of the } \\
\text { English course }\end{array}$ & 70 & 2.79 & 1 & 5 \\
\hline $\begin{array}{l}\text { choosing the following topic } \\
\text { for the courses }\end{array}$ & 70 & 2.80 & 1 & 5 \\
\hline $\begin{array}{l}\text { selection of the activities for } \\
\text { the courses }\end{array}$ & 70 & 2.26 & 1 & 5 \\
\hline $\begin{array}{l}\text { decision on the length of the } \\
\text { activity during lessons }\end{array}$ & 70 & 2.11 & 1 & 5 \\
\hline $\begin{array}{l}\text { Selecting the classroom } \\
\text { materials }\end{array}$ & 70 & 2.33 & 1 & 5 \\
\hline assessing learning & 70 & 2.13 & 1 & 5 \\
\hline lesson assessment & 70 & 3.00 & 1 & 5 \\
\hline $\begin{array}{c}\text { choosing what to learn as out } \\
\text { of class learning }\end{array}$ & 70 & 4.04 & 1 & 5 \\
\hline
\end{tabular}

Table 6 displays the students' responsibility perceptions notion for learning. Deciding on how long to spend on each activity has the minimum mean $(M=2.11)$ along with evaluating their learning $(M=2.13)$ while deciding on what they learn outside the class carries the highest mean $(M=4.04)$. It could be stated that the students do not find themselves adequate to make evaluation about their learning progress and determining how much time to spend on the activities. Additionally, the average mean is 2.67 which is in between the responsibility of the items mentioned in table 5 belongs to 'half student's, half teacher's. When the average results of the students' evaluation of their learning engagement at high school $(M=2.04)$ and their present perceptions towards the responsibility notion for learning $(M=2.67)$ are compered, it could be concluded that they tend to become autonomous learners at preparatory school.

Table 7. Students perceptions towards their abilities

\begin{tabular}{ccccc}
\hline & N & Mean & \multicolumn{2}{c}{ Minimum Maximum } \\
selecting activities for courses & 70 & 3.23 & 1 & 5 \\
selecting out of class activities & 70 & 3.36 & 1 & 5 \\
selecting course objectives & 70 & 2.74 & 1 & 5 \\
selecting out of class learning & 70 & 3.34 & 1 & 5 \\
$\begin{array}{c}\text { objectives } \\
\text { course material selection }\end{array}$ & 70 & 3.11 & 1 & 5 \\
out of class material selection & 70 & 3.41 & 1 & 5 \\
assessing learning process & 70 & 2.79 & 1 & 5 \\
$\begin{array}{c}\text { assessing lessons } \\
\text { describing your weaknesses }\end{array}$ & 70 & 3.04 & 1 & 5 \\
choosing the following topic to & 70 & 2.54 & 1 & 5 \\
learn & 2.76 & 1 & 5 \\
\hline
\end{tabular}

Most of the students believe that they are at the beginning of 'good' scale with 3.03 average mean in terms of their abilities in taking actively part in learning decision process. The majority of them $(M=3.41)$ see themselves capable of choosing learning materials outside the class and choosing learning activities outside class $(M=3.36)$. The lowest mean is $(M=2.54)$ identifying their weaknesses in learning English. The average mean shows that the students' ability perception to be autonomous learners have changed positively at the university.

Table 8. Students' motivation perception

$\begin{array}{ccc}\text { How would you define your level of motivation to learn English? } & \text { Valid } & 70 \\ \mathrm{~N} & \text { Missing } & 0 \\ \text { Mean } & & 3.76 \\ \text { Minimum } & & 1 \\ \text { Maximum } & \underline{100} & 5 \\ \text { Percentiles } & \end{array}$

The table indicates that the students accept themselves as 'well-motivated' to learn English at university preparatory school. It is possible to conclude the students' motivation perception could be related to the preparatory school's modern curriculum and instructors' support. 
Table 9. Activities done by the students without being assigned to do so

\begin{tabular}{|c|c|c|c|c|}
\hline & $\begin{array}{c}\mathrm{N} \\
\text { Valid }\end{array}$ & Mean & Minimum & Maximum \\
\hline studying grammar books & 70 & 2.49 & 1 & 5 \\
\hline Keeping vocabulary notebook & 70 & 2.81 & 1 & 5 \\
\hline sending letters to your friends & 70 & 1.44 & 1 & 3 \\
\hline reading English newspapers & 70 & 1.96 & 1 & 4 \\
\hline sending mails in English & 70 & 2.53 & 1 & 4 \\
\hline reading books or magazines in English & 70 & 2.53 & 1 & 5 \\
\hline watching English channels on television & 70 & 2.74 & 1 & 4 \\
\hline listening to English radio & 70 & 2.41 & 1 & 5 \\
\hline listening to English songs & 70 & 3.00 & 1 & 4 \\
\hline speaking English with native speakers & 70 & 2.74 & 1 & 5 \\
\hline speaking English with friends & 70 & 2.54 & 1 & 4 \\
\hline watching English films & 70 & 3.06 & 1 & 4 \\
\hline keeping a diary in English & 70 & 2.24 & 1 & 4 \\
\hline using the Internet in English & 70 & 3.29 & 1 & 5 \\
\hline Reviewing your classroom notes & 70 & 2.71 & 1 & 4 \\
\hline attend a self-study center & 70 & 1.99 & 1 & 4 \\
\hline asking to your teacher about your study & 70 & 2.97 & 1 & 4 \\
\hline ask the teacher questions when you do not understand & 0 & 3.11 & 1 & 4 \\
\hline sharing your ideas with your teacher & 70 & 2.51 & 1 & 4 \\
\hline Try to to speak English at any time & 70 & 3.33 & 1 & 4 \\
\hline
\end{tabular}

The table above illustrates the activities done by the students without being assigned to do so.

The lowest means gradually are sending letters to their pen-friends $(M=1.44)$, reading newspapers in English $(M=1.96)$ and attending a self-study center $(M=1.99)$. The highest mean belongs to taking opportunities to speak English $(M=3.33)$ which means students are motivated to use English within and out of the classroom. Additionally, the items of using the Internet in English $(M=3.29)$, watching English movies $(M=3.06)$ and listening to songs $(M=3.00)$ have the high means, which predicate the students like using technology and fun activities. Besides, most of the students ask questions to the teachers when they do not understand $(M=3.11)$ and the result shows more than $\% 60$ of the students have self-esteem to ask questions for additional information.

\subsection{Preparatory School Instructors' Perceptions about Students' Autonomy Readiness}

The researchers conducted some interviews with four preparatory school instructors to acquire their perceptions about autonomy readiness level of the students. Based on the interviews, it could be concluded that the students are not still ready to be autonomous learners because of some reasons. First, the instructors stated that the students try to memorize the summary of the story books for their portfolio class; however, they are supposed to retell the stories with their own words to practice the language. The teachers think that most of the students are used to memorize the language items at high schools and they are reluctant to deal with additional learning materials such as extra handouts, readers or activities. Secondly, as the instructors have observed the students' learning engagement outside of the classroom, they have realized the students are reluctant to endeavor for their self-learning. Even if the instructors guide them for some tasks such as reading books, preparing portfolio, watching movies, practice speaking or attending discussion forums to enhance their autonomy, their participation level is not at intended level, or they hesitate to make decisions on their own to make advancement in learning process according to the instructors. However, the students are more ready to be autonomous learners in preparatory school comparing to their high school experience and present motivation level for being independent learners.

\section{Limitations of the Study}

The sample of the research consists of one of the private universities' preparatory school students in Erbil so the results cannot be generalized for all EFL learners. Furthermore, if the data were collected from public university students, different results might have been obtained. 


\section{Conclusions}

The results demonstrate that the students' former autonomy level may negatively have affected their responsibility perception since most of the them stated their teachers were authoritarian at high school. That is, they were not encouraged to participate in learning process and make decisions for their own learning. Moreover, they described themselves as more teacher-dependent when they were high school which prevented them from setting personal learning goals, evaluating their learning level and making decisions on what, how, why or when to learn and material selections. For instance, the minority of the students indicated that they used to keep portfolio at high school, yet portfolio keeping is accepted to motivate students to be autonomous learners because the students should take responsibility to track their own learning progress.

The students' perceptions about their responsibilities at preparatory school are not still satisfactory to accept them as autonomous learners regarding the results. For instance, they think the responsibilities for tracking their learning inside or outside of the classroom; identifying their weaknesses and strengths and making decisions on material selections belong to half theirs and half teachers. Besides, the students believe they have moderate abilities to take their learning responsibilities even though the preparatory instructors encourage them to do so. This reveals that the students have hesitation for self-esteem to take their own learning responsibility.

On the other hand, the students describe themselves as motivated at preparatory school. However, the instructors claim that the motivation level does not overlap with their actual performance level regarding their effort to make reflection on their learning process adequately or take responsibility inside or outside of the classroom. Also, another notable result emerges in the activities part on which most of the students 'sometimes' deal with the language activities in their daily lives like reading books, listening to songs, watching movies, speaking with native speakers and etc. without having been assigned to do so. The students' present readiness seems quite better when it is compared to the level of autonomy at high school, yet the instructors still do not find the result adequate to accept the students as autonomous learners as required at university level.

\section{REFERENCES}

[1] Bala, E. \& Bala, A., "Learning to Learn: Strategopedia," International Journal of Social Sciences \& Educational Studies, vol. 5, no. 2, pp. 164-170, 2018. DOI: 10.23918/ijsses.v5i2p164
[2] Cohen, L., Manion, L., \& Morrison, K., "Research Methods in Education," Routledge, 2013, pp. 1-753.

[3] Gholami, H., "Self-assessment and Learner Autonomy," Theory and Practice in Language Studies, vol. 6, no. 1, pp. 46-51, 2016. DOI: http://dx.doi.org/10.17507/tpls.0601.06

[4] Holec, H., "Autonomy and Foreign Language Learning," Pergamon Press, 1981.

[5] Karabiyık, A., "The Relationship between Culture of Learning and Turkish University Preparatory Students' Readiness for Learner Autonomy," PhD diss., Bilkent University, 2008.

[6] Khamees, K. S., “An Evaluative Study of Memorization as a Strategy for Learning English," International Journal of English Linguistics, vol. 6, no. 4, pp. 248-259, 2016.

[7] Lazăr, A., "Learner Autonomy and its Implementation for Language Teacher Training," Procedia-Social and Behavioral Sciences, vol. 76, pp. 460-464, 2013. DOI: https://doi.org/10.1016/j.sbspro.2013.04.146

[8] Little, D. G., "Learner Autonomy: Definitions, Issues and Problems," Authentik, 1991.

[9] Little, D., "Learner Autonomy: Why Foreign Languages Should Occupy a Central Role in the Curriculum" in New Perspectives on Teaching and Learning Modern Languages, Multilingual Matters, 2000, p.24-45.

[10] MacNeil, A. J., Prater, D. L., \& Busch, S., "The Effects of School Culture and Climate on Student Achievement," International Journal of leadership in Education, vol. 12, no. 1, pp. 73-84, 2009. DOI: https://doi.org/10.1080/136031207 01576241

[11] Palfreyman, D., "Introduction: Culture and Learner Autonomy," In Learner Autonomy Across Cultures, Palgrave Macmillan, 2003, pp. 1-19.

[12] Palfreyman, D., \& Smith, R. C., "Learner Autonomy Across Cultures: Language Education Perspectives," 1st ed, Palgrave Macmillan, 2003, pp. 1-299. DOI: 10.1007/978-0230-504

[13] Smith, R., "Learner Autonomy," ELT Journal, vol. 62, no. 4, pp. 395-397, 2008. DOI: https://doi.org/10.1093/elt/ccn038

[14] Thomas, D. R., "A General Inductive Approach for Qualitative Data Analysis," American Journal of Evaluation, vol. 27, no. 2, pp. 237-246, 2003.

[15] Tran, T. Q., \& Duong, T. M., "EFL Learners' Perceptions of Factors Influencing Learner Autonomy Development," Kasetsart Journal of Social Sciences, vol. 41, no. 1, pp. 2018. DOI: https://doi.org/10.1016/j.kjss.2018.02.009

[16] Üstünlüoğlu, E., “Autonomy in Language Learning: Do Students Take Responsibility for Their Learning?," Journal of Theory \& Practice in Education, vol. 5, no. 2, pp. 148-170, 2009.

[17] Zulu, B. M., Urbani, G., Van der Merwe, A., \& Van der Walt, J. L., "Violence as an Impediment to a Culture of Teaching and Learning in Some South African Schools," South African Journal of Education, vol. 24, no. 2, pp. 170-175, 2004. 